\title{
Visionary Prefab in the Modern Age: Deconstructing Keaton's Films
}

Dr. Cristian Suau,

Welsh School of Architecture

suauc@cardiff.ac.uk

\begin{abstract}
This essay analyses Buster Keaton's masterpieces: One Week (1920); The Haunted House (1921) and The Electric House (1922). His filmic work reveals the montage of mass housing prefabrication in the Modern Age in the United States: Repetition and mechanisation of the building production; generic layouts; and modular like-catalogue constructions. Rather than following a sequential building process, these cases are executed as mere accidents or flaws. Buster Keaton's films however show ironically a nonstandardized architecture. For instance, One Week is the story of the seven-day construction process of Sears's mail order Modern Home ${ }^{1}$, a standard catalogue house, with pre-cut fitted pieces and appliances. The ability to mass-produce the materials used in Sears's homes narrowed manufacturing costs, which lowered purchase costs for customers. Not only did pre-cut and fitted materials shrink construction time up to $40 \%$ but Sears's use of balloon framing, plasterboard, and shingles greatly eased fabrication for home-buyers. Nevertheless, Sears's designs offered distinct advantages over other construction methods.
\end{abstract}

The Electric House focuses on mechanical appliances. Both films announce a new architecture where walls might fold over; floors shift; an escalator replaces the staircase; the foundation rests on wheels; the programme metamorphoses and the appliances organise the domestic life. Parts could leave the site and return, or the entire building could collapse or become mechanised, folded up or simply be transported to a different location.

As visionary Modern architecture, there are particular features that will be analysed in depth: The expanding functions; variable divisions of interior space; and flexible and automated furniture and appliances.

What might a non-standard manufacturing Modern house look like? Keaton creates a parody-manifesto against MOMO's mass production. Keaton anticipates the architecture in motion envisioning adaptable, light and compact spaces, with dwellers in transit. In Keaton's work, the ability to move, change or adapt are prerequisites for Modern living. This study will analyse and compare Keaton's filmic production with Catalog Modern House, a prefab dwelling manufactured and shipped by Sears, Roebuck and $\mathrm{Co}^{2}$ in the beginning of $20^{\text {th }}$ century.

\footnotetext{
${ }^{1}$ Sears Catalog Homes: People had learned to trust Sears for other products bought mail-order, and thus, sight unseen. This laid important groundwork for supplying a home, possibly the largest single purchase a typical family would ever make. In 1908, the company began offering entire houses as kits, marketed as Sear Modern Homes, and by the time the program ended in 1940, over 100,000 had been sold. Source: Source: accessed in 27.09.2009, http://www.searsarchives.com/homes

2 According to Colin Davies in his book The Prefabricated Home (2005, p.25), "Sears Roebuck never claimed to make any contribution to the progress of Modern Architecture". The company was instead a follower of non-architect home designs, generic rather than monumental; but with the ingenious advantage of modifying and adaptable houses. Sears introduced the latest technology available to modern US dwellers in the early part of the twentieth century. Central heating, indoor plumbing, and electricity were all new developments in home design that Modern Homes incorporated. Indoor plumbing and homes wired for electricity were the first steps to modern kitchens and bathrooms. Sears Modern Homes program stayed
} 


\section{Keaton's Houses: Living Systems in Motion}

"Nearly every American house I've lived in has long ago been demolished to make room for some other building. There is a delicious (though painful) paradox here: Americans long for stability, but all they get is stationary impermanence. No wonder then many of us long to become permanent nomads, snails with houses on our backs, Touareg tribesmen, and Gypsies". Poet Andrei Codrescu ${ }^{3}$

The limits of architecture flow between what is stationary and what is in motion. What happens to architecture when foundations are removed? To investigate this question, it is useful to look at the origins of prefabricated houses. Beside what the architectural scene has written about the failure of prefab systems, the fact is that these constructions have succeeded. Luckily architecture is not yet commodity but art.

Nowadays proceeding on the assumption that social change and a change of residence are closely correlated, post-modern sociologists aim to gain an understanding of societal trends such as pluralisation and flexibility, and thus to draw recommendations about future housing requirements. Living in motion indicates that modes of housing are becoming visibly pluralised, moving away from canonical models towards a new type of contentdesign mobility. As classic models of nuclear families erodes, new housing forms are emerging that offer new flexible ways of living.
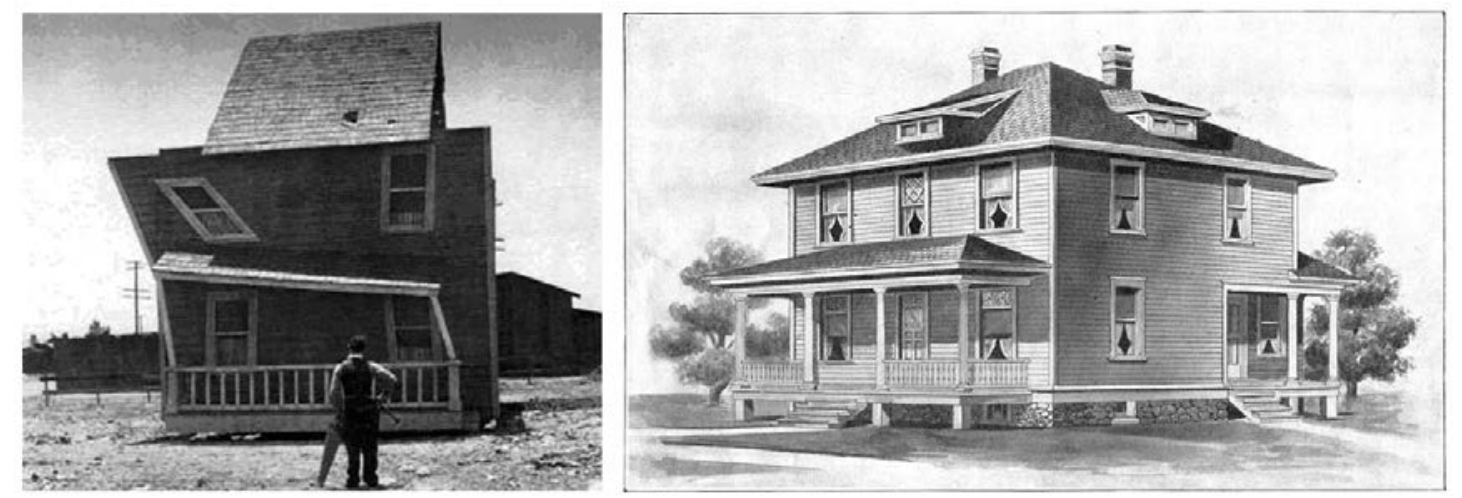

Figure 1. Keaton versus Sears Modern Home: While Sears factory was manufacturing and shipping catalogue houses like Modern Home 102 (right image); Keaton was building his 'customized version' of a similar mail-order Modern Home in the film One Week (left image). Sources:

http://www.archive.org/details/OneWeek and Sears Archives, http://www.searsarchives.com/homes

Keaton was a visionary architect. As an organiser he was obsessed with the idea of capturing the Modernity of domestic life mainly by the house as a kinetic lab. In order to illustrate this let us consider some key examples. One Week, is a short-comedy film written, directed and performed by Keaton. Many special effects are employed were filmed as they occurred and were not the result of model work.

The story involves a couple, Keaton and Seely, who receive a build-it-yourself house as a wedding gift. The house can supposedly be built in one week. A jealous party secretly renumbers the packing boxes containing the house parts. The movie recounts Keaton's struggle to assemble the house according to this new random arrangement. As if this weren't enough, Keaton finds he has built his house on the wrong site and has to move it.

abreast of any technology that could ease the lives of its homebuyers and gave them the option to design their homes with modern convenience in mind.

Source: accessed in 27.09.2009, http://www.searsarchives.com/homes

${ }^{3}$ Siegal, J. Mobile: The Art of Portable Architecture, Foreword by Andrei Codrescu. 2002, Princeton

Architectural Press, New York, p. 10 
Wheels replace the original foundations and the house is moved like a caravan by car. This short film achieves its peak when the house, now a mobile device, becomes stuck on railway tracks on which a train is coming. The house remains static and the train hits it producing a shower of wreckage. Keaton stares at the scene, places a 'For Sale' sign with the heap and walks off with Seely.

At the same time Le Corbusier was carrying out preliminary sketches for the Maison Citrohan; a mass-produced house type ${ }^{4}$. The shape is basically a non-ornamental whitened cube. The paradox is that the reinforced concrete structural frame was constructed on-site and bearing walls were filled with local materials. We can deduce that this standardized prototype was a result of the romantic idea of industrial fabrication. This purist object was not an off-site invention but the artisan reproduction of unachievable machinery.
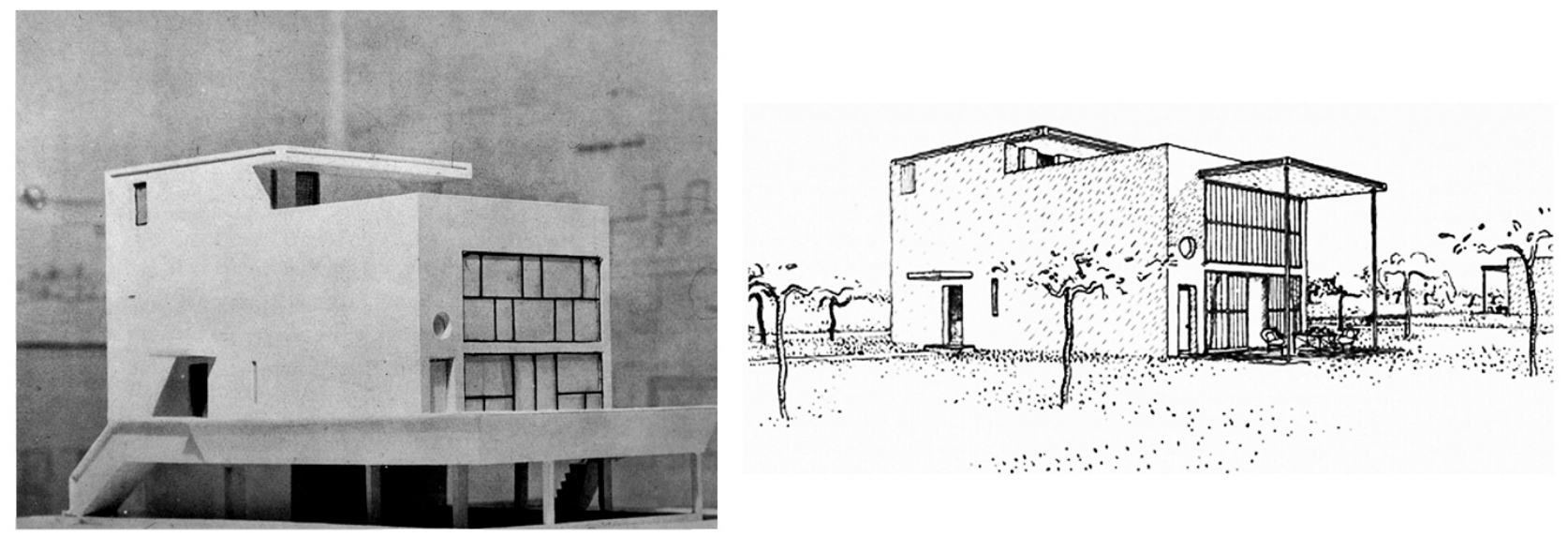

Figure 2. Maison Citrohan by Le Corbusier. Plaster model (left) and sketch (right), 1920-1922. Le Corbusier's initial vision of adopting mass-production techniques never developed to what he had envisioned. Unfortunately off-site housing fabrication is still associated with the idea of automated shoe boxes, allocated in trailer parks or the like. Source: Fondation Le Corbusier (Archives).

Nonetheless, how can we define the house we are confronted with in Buston Keaton's One Week? By investigating several of Keaton's silent films and comparing them with the housing production in the US around the same period, we are able to obtain some remarkable outcomes.

The house in One Week is similar in shape and sizing to the Sears Modern Home, prototype 102, which was published in the 1920's Catalogue called Honor Bilt, Modern Home. The film's script is structured according to the Catalog Modern House's framework: mailing, shipping, delivering and rapid-building. The film critic Malcolm $\mathrm{H}$. Oettinger, in his essay called Low Comedy as a High Art (1923) ${ }^{5}$ described the One Week house, saying that" (...) Buster has ordered a Sears-Roebuck ${ }^{6}$ bungalow for his bride-to-be. The wicked

\footnotetext{
${ }^{4}$ The French term Maisons en Séries use by Le Corbusier does not imply the Anglo-Saxon notion of factory or off-site production. It is an even definition of industrial fabrication, which can tolerate on-site fabrication and components.

${ }^{5}$ Oettinger, M. Low Comedy as a High Art (1923) Picture-Play Magazine. Source: access in 02/02/2008 http://www.geocities.com/ oldbrit/bkppint2.htm

${ }^{6}$ Sears Catalogue Homes. People had learned to trust Sears for other products bought mail-order, and thus, sight unseen. This laid important groundwork for supplying a home, possibly the largest single purchase a typical family would ever make. In 1908, the company began offering entire houses as kits, marketed as Sears Modern Homes, and by the time the program ended in 1940, over 100,000 had been sold. Source: http://en.wikipedia.org/wiki/Sears,_Roebuck_and_Company\#Sears_catalog_homes
} 
rival mixes the numerals on the various parts, and the comedy ensues when Buster attempts to assemble the jazzed sections".

The One Week housing model as collapsible design is classified according to their uses or capabilities: Transportability; adaptation; combination; assembling and disassembling process; and folding/unfolding. Therefore, the One Week house is a complete organism. Its initial generic housing pattern is modified, by altering the sequence of packing boxes containing the house parts. The One Week house is a sort of customised variation of the so-called Catalog Modern House, a prefab dwelling manufactured and shipped by Sears, Roebuck and Co.
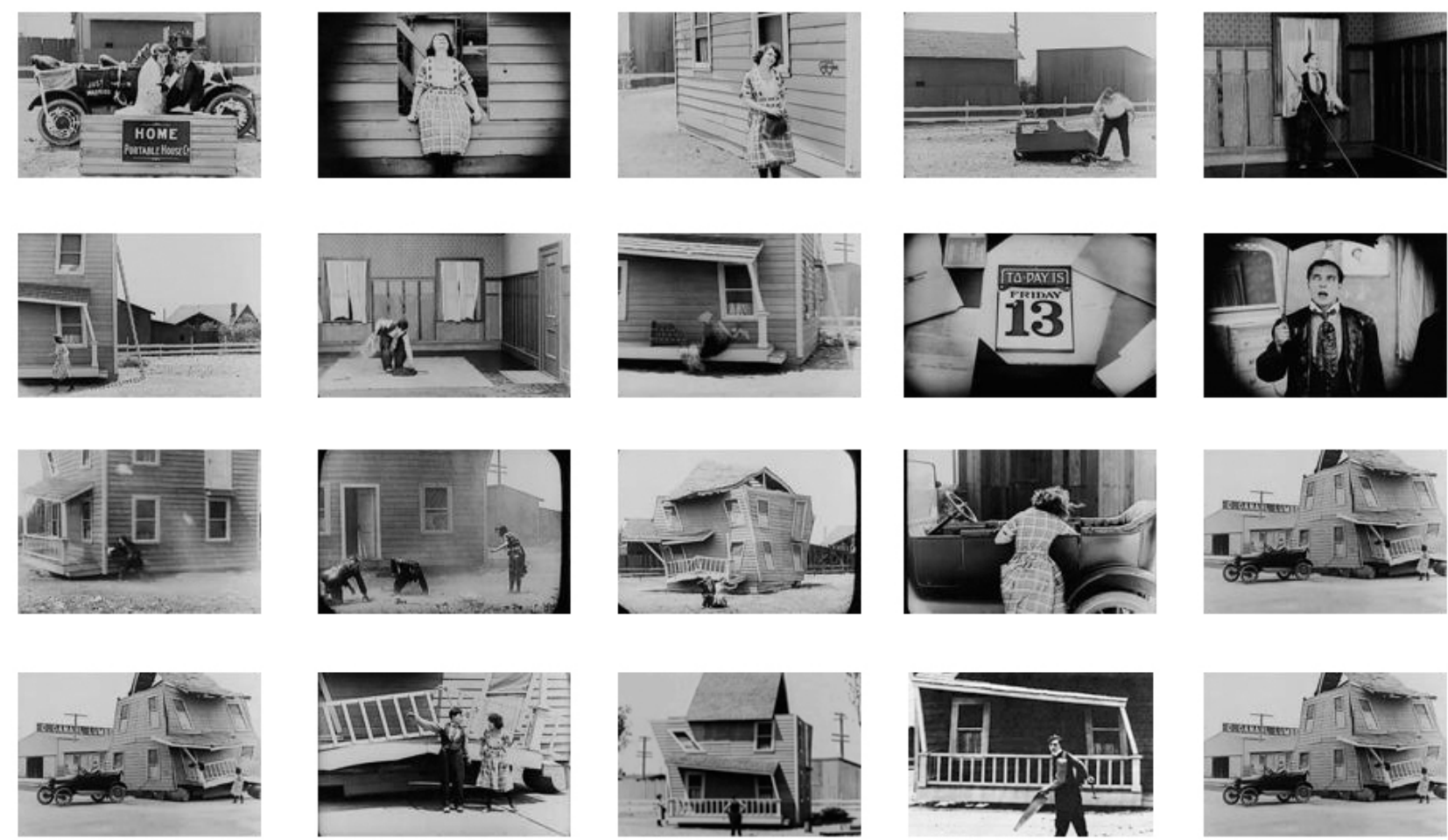

Figure 3. Serial of One Week (1920) by B. Keaton. Source: http://www.archive.org/details/OneWeek

\section{Modern Conveniences and Appliances: Towards Customised Prefab}

If One Week was an investigation of the Sears Modern Home as a collapsible and mobile hardware, The Haunted House (1921) and The Electric House ${ }^{7}$ (1922) were focused on mechanical appliances, simply innovative domestic devices, providing a great deal of comic business for Keaton.

The Electric House represents a visionary conceptualisation of the house as a plug-in system, which performs as a sort of software. The idea of electrical innovation was naturally in the forefront of people's minds in the early years of the 20th century. The goal of the film was to keep the existing house framework but to electrify everything in the professor's house, both furniture and devices. For example, a mechanical type stairway -

\footnotetext{
${ }^{7}$ The Electric House (1922). Director: Buster Keaton. Cast: Buster Keaton; Joe Roberts; Virginia Fox; Joe Keaton; Myra Keaton; and Louise Keaton. Originally this film started shooting in 1921, but an accident on the set forced all the previously shot footage to be abandoned and the film entirely reshot on a newly designed set in 1922. The Electric House starts with Buster's graduation ceremony as the first of his comic misfortunes, including a mix-up of diplomas so Buster receives a diploma in electrical engineering. This leads to a job opportunity: electrifying the family house of the girl he's sweet on. A great chance, so Buster studies hard and soon installs a useful and impressive set of electric appliances.
} 
which could be reversed- was a pioneering idea that later became practical in department stores in the form of the escalator. Here Keaton brings this device into domestic life.

In addition, the pool table, which racks its own balls, has become available to us. Conveyer belts are in evidence along with electric trains for bringing food and dishes to the dining table. Buster Keaton, of course, adds the enthusiasm to the Swedish smörgåsbord or banquet of comedy delights.
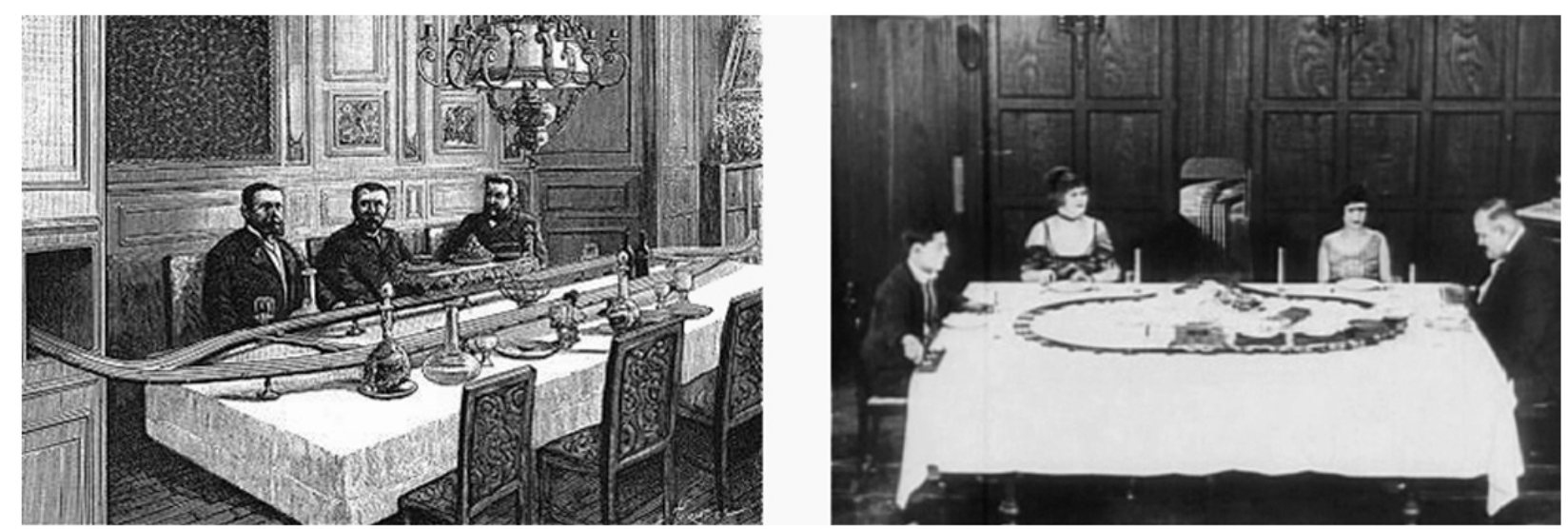

Figure 4. Learning from a railway loop. Right, the electric table (Le Chemin de Fer de Table) by Gaston Menier, 1887. Left, Dining table as railway track in The Electrical House by Keaton (1922).

Such as Keaton shows in The Electric House, Sears introduced the latest technology available to modern US dwellers in the early part of the twentieth century. Central heating ${ }^{8}$, indoor plumbing, and electricity were all new developments in home design that Modern Homes incorporated. Indoor plumbing and homes wired for electricity were the first steps to modern kitchens and bathrooms. Sears Modern Homes program stayed abreast of any technology that could ease the lives of its homebuyers and gave them the option to design their homes with modern convenience in mind.

Ironically in The Electrical House, all new appliances fail. This failure is in turn used to generate comedy; the accident is the generator of inventions and each thoroughly envisions new needs in the Modern domestic life.

\section{Sears Mail-order Homes: Standardization and the D.I.Y. (Do-It-Yourself)}

Purchasing a house from a mail-order catalogue seems like a fantastic story made for comedy value but in fact it was a pioneered practice in the US in the 20's. The entire process consisted of the following sequence: catalog or pattern book design; mail order; pre-cut timber fabrication (balloon frame); and shipping and delivery by rail, typically in two boxcars each.

The Sears prefab house has been chosen as a drive for discussion not only because it is a current topic of critique but also because it challenges the reductive notion of what architecture should be. According to Sears' archives, 'from 1908-1940, Sears, Roebuck

\footnotetext{
${ }^{8}$ Central heating not only improved the livability of homes with little insulation but it also improved fire safety, always a worry in an era where open flames threatened houses and whole cities, in the case of the Chicago Fire. Source: accessed in 04.02.2008, http://www.searsarchives.com/homes
} 
and Co. sold about 70,000 - 75,000 homes through their mail-order Modern Homes program. Over that time Sears designed 447 different housing styles"'.

To buy a house in kit form saved about $40 \%$ on labour costs; quality custom design and favourable financing; and provided accuracy and efficiency of the machine-cutting timber. Apart from this, customers could choose a house to suit their individual tastes and budgets. Modern Home's customers had the choice to build their own dwellings. All these features are exaggerated but still remain in One Week, creating a random pattern based on the mixed-up sequence of parts.

Sears was not an innovative home designer. According to Colin Davies, "Sears Roebuck never claimed to make any contribution to the progress of Modern Architecture"10. The company was instead a follower of non-architect home designs, generic rather than monumental; but with the ingenious advantage of modifying and adaptable houses, both hardware and software, according to buyer's way of living ${ }^{11}$.

\section{Patching Balloon-Frames}

Rather than a frame-maker Sears was a patch-maker. Instead of introducing a new physical framework or becoming an innovator in home design or construction techniques, he was producing a conceptual system where the 'patches' ${ }^{, 12}$ can be fabricated in any order and assembled together in any number of permutations. In the manufacturing sector, the components are the patches. However, Sears's designs did offer distinct advantages over other construction methods.

The ability to mass-produce the materials used in Sears's homes narrowed manufacturing costs, which lowered purchase costs for customers. Not only did precut and fitted materials shrink construction time up to $40 \%$ but Sears's use of balloon framing, plasterboard, and shingles greatly eased fabrication for home-buyers:

A. Chassis. Essentially balloon-frame ${ }^{13}$ is a wall and flooring timber modular system. Foundations and roofs vary in sizes. This system uses precut standard timber for framing. The walls are formed by vertical studs $(50 \mathrm{~mm}$ times $100 \mathrm{~mm})$ in cross section, spaced at $400 \mathrm{~mm}$ in apart and nailed to horizontal plates top and bottom. In a two-storey house, the studs extend over the entire height, with a ribbon let into them on the inside, to bear the joists or beams of the upper floor. When the framing is completed, it is covered with siding, traditionally of overlapping timber clapboards nailed to the studs. The Balloon Frame systems did not require skilled carpenters, as previous constructive methods. Sears' balloon frames were built faster and generally only required one carpenter. Precut timber,

\footnotetext{
${ }^{9}$ Nevertheless, no official tally exists of the number of Sears mail-order houses that still survive today. It is reported that more than 100,000 houses were sold between 1908 and 1940 through Sears's Modern Homes program. The keen interest evoked in current homebuyers, architectural historians, and enthusiasts of American culture indicate that thousands of these houses survive in varying degrees of condition and original appearance. Source: accessed in 04.02.2008, http://www.searsarchives.com/homes

10 Davies, C. The Prefabricated Home, 2005, London, Reaktion Book Ltd., p53

${ }^{11}$ Individuals could even design their own homes and submit the blueprints to Sears, which would then ship off the appropriate precut and fitted materials, putting the home owner in full creative control. Source: accessed in 04.02.2008, http://www.searsarchives.com/homes

${ }^{12}$ Framing is a system where several parts are aggregated into a whole. Patching it is a non-linear system. It consists of elements that are made in different locations and then assembled to form the whole. It is based on less segregation and ore integration.

${ }^{13}$ Balloon frame was invented in 1833 in Chigago, US.
} 
fitted pieces, including the nails, and shipped by railroad directly to the customer made popular this frame-kit.
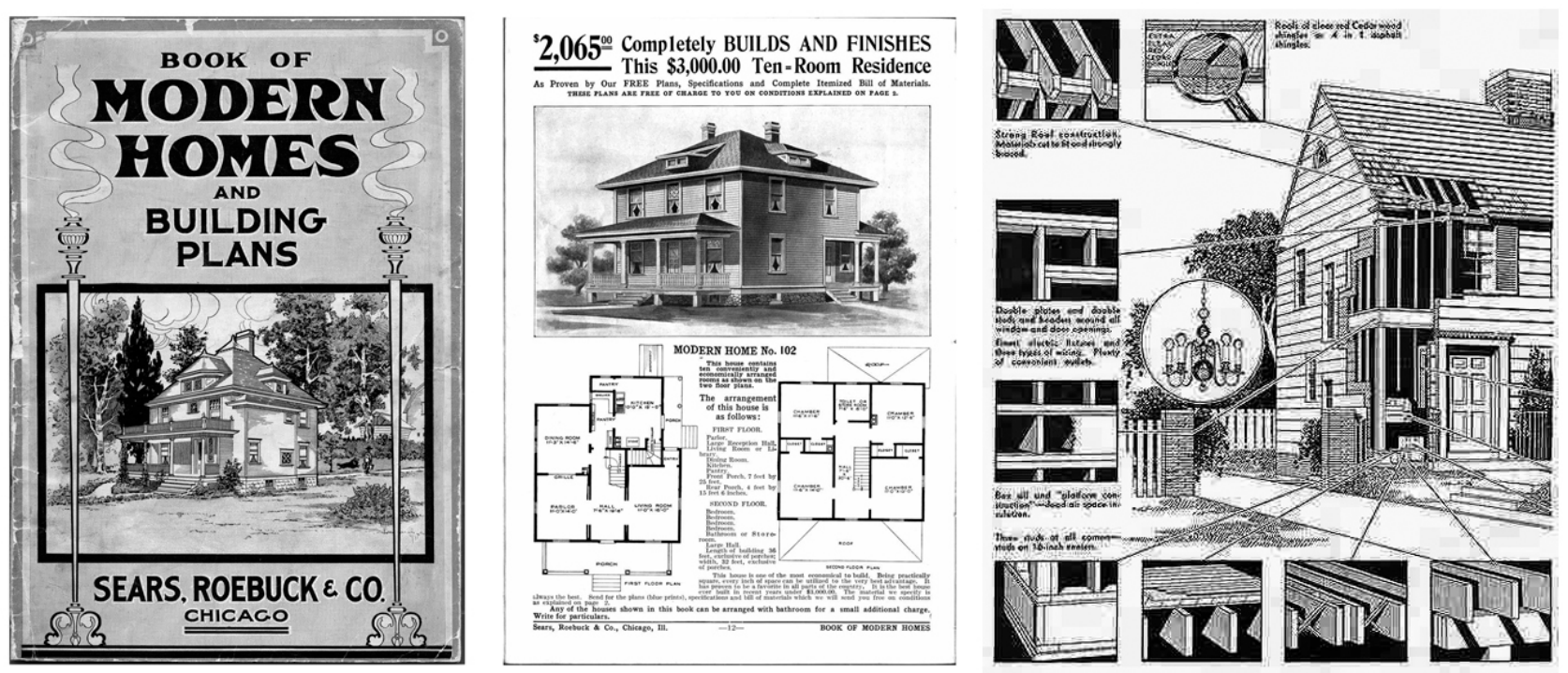

Figure 5. The Sears Modern Home: Catalogue, Type and Framing. Sears Archives,

http://www.searsarchives.com/homes

B. Plasterboards. Before drywall (US term for plasterboard), the most common wallbuilding techniques were plaster and lathe. Sears housing fabrication took advantage of the new material called drywall by shipping large quantities of this inexpensively manufactured product with the rest of the housing components. Drywall offered advantages of low price, ease of installation, and was added fire-safety protection.

C. Shingles. According to the Sears archives: "It was during the Modern Homes program that large quantities of asphalt shingles became available. The alternative roofing materials available included, among others, tin and wood. Tin was noisy during storms, looked unattractive, and required a skilled roofer, while wood was highly flammable. Asphalt shingles, however, were cheap to manufacture and ship, as well as easy and inexpensive to install". Asphalt is also a fireproof material.

\section{Finale: Fabrication out of control}

Process sets the stage for the outcome ${ }^{14}$.

Beyond this synopsis, what are the Keaton houses? They are simple mistakes, ungovernable places. Nevertheless, Keaton's housing design introduces three features: flexible plan, advances in construction technology and the role of the individual in the design process.

His houses capture the random daily activities in domestic scales and mostly ruled by fortuitous circumstances. Morphologically they are extreme dwellings, treated in a radical way. Through Keaton, modular fabrication is no longer a result of mass production, repetition, and uniformity. Keaton's housing design consists of: transformable and polyvalent plans; customised fabrication; and engagement of users within the assemblage process.

\footnotetext{
${ }^{14}$ Kieran, S. \& Timberlake, J. Refabricating Architecture, 2004, New York, RR Donnelley. P 107
} 

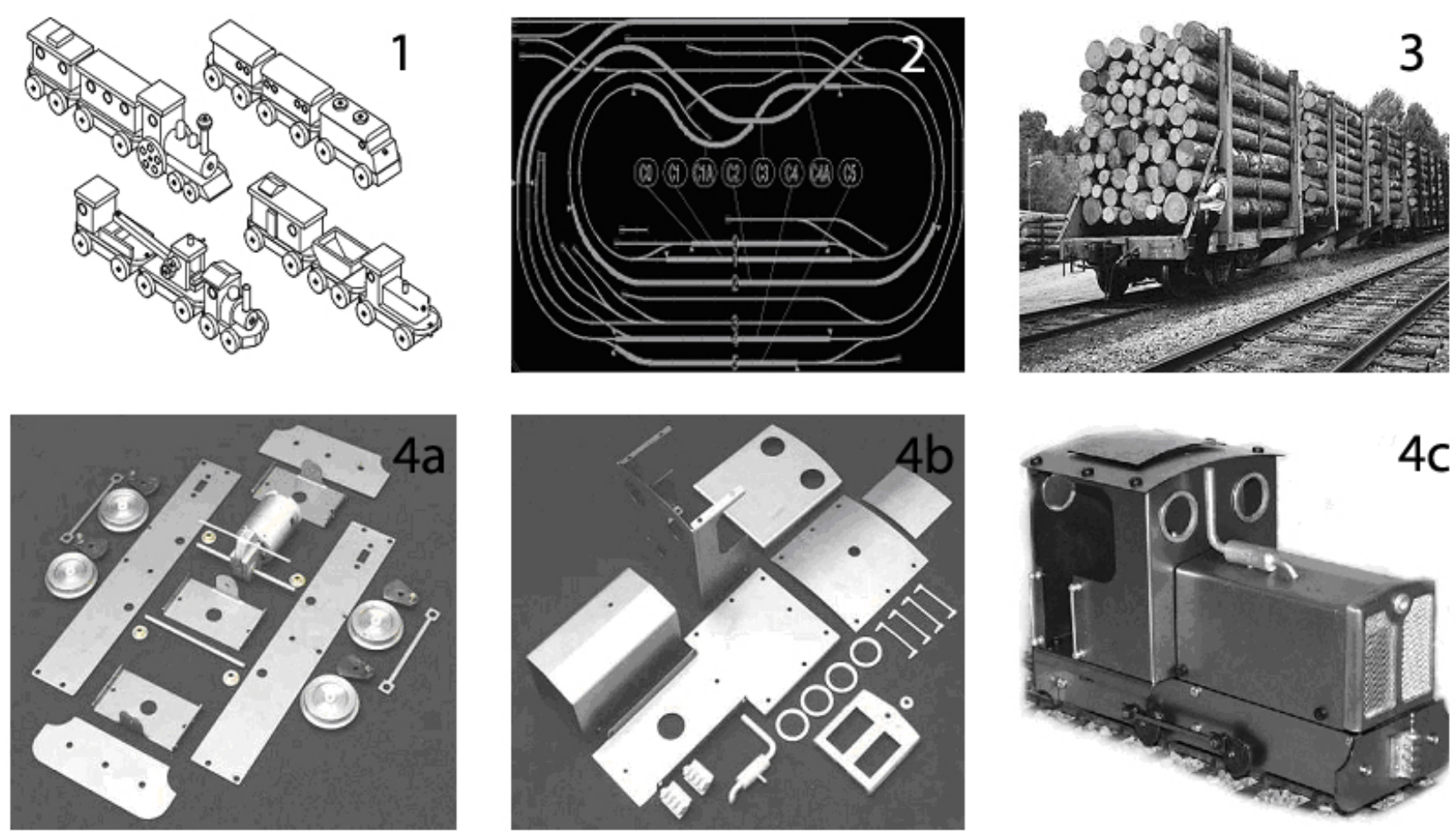

Figure 6. Fabrication of the Keaton's House: 1. House as a game; 2. House as organism; 3. House as movable system; and 4. House a easy-to-make kit. Source: Cristian Suau's private collection

Keaton's films envision the idea of mass customization as a hybrid system. They conceived new building processes using manufacturing/automated production but with the ability to differentiate and personalised spaces and appliances for those that are generically fabricated.

In opposition to traditional aesthetic of the Modern Avant-garde, Keaton's houses are always machines for failure. In a classical sense, only the accident generates the invention.

\section{References}

Eisenstein, S. Film Form. 1949, New York, Harcourt Brace Publisher

Deleuze, G. Cinema 1: The Movement-Image; Cinema 2: The Time-Image (2 volumes). 1989, London, Athlone Press.

Wender, W. The Logic of Images, 1991. London, Faber \& Faber

Lamster M. Architecture and Film, 2000. New York, Princeton Architectural Press

Gorostiza, J. La Profundidad de la Pantalla, 2007. Santa Cruz de Tenerife, Colegio de Arquitectos de Canarias

Siegal, J. Mobile: The Art of Portable Architecture, 2002. New York, Princeton Architectural Press

Schwartz-Clauss, M. Living in Motion - Design and Architecture for Flexible Dwelling, 2002. Bassel, Vitra Design Museum

Leupen, B. Frame and Generic Space, 2006. Rotterdam, 010 Publishers Robb, B. Silent Cinema, 2007. London, Kamera Books

Davies, C. The Prefabricated Home, 2005, London, Reaktion Book Ltd.

Kieran, S. \& Timberlake, J. Refabricating Architecture, 2004, New York, RR Donnelley.

Gorostiza, G. Paradigmas (Paradigms), Projecciones y Utopias de la Vanguadia, 2007. Madrid, La Fabrica. 
The International Buster Keaton Society: http://www.busterkeaton.com

Sears Archive: http://www.searsarchives.com/homes 